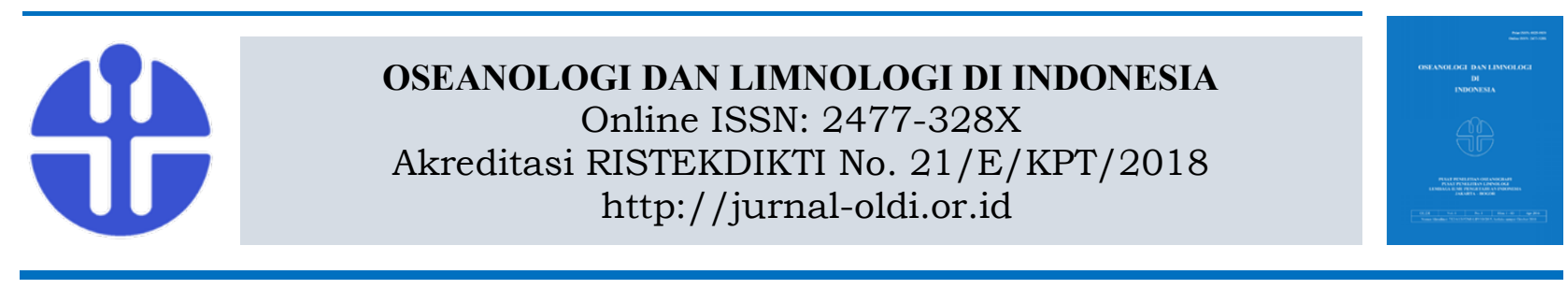

\title{
Kontaminasi Logam Berat di Kawasan Pesisir Tanjung Selor Kalimantan Utara
}

\author{
Tri Muji Susantoro ${ }^{1}$ dan Ariani Andayani ${ }^{2}$ \\ ${ }^{1}$ Pusat Penelitian dan Pengembangan Teknologi Minyak dan Gas Bumi, LEMIGAS \\ ${ }^{2}$ Pusat Riset Perikanan, Badan Riset dan Sumber Daya Manusia Kelautan dan Perikanan, KKP \\ E-mail: trimuji_s@yahoo.com
}

Submitted 18 January 2018. Reviewed 13 August 2018. Accepted 7 December 2018.

DOI: 10.14203/oldi.2019.v4i1.181

\begin{abstract}
Abstrak
Terbentuknya Provinsi Kalimantan Utara mengubah wilayah Tanjung Selor dan sekitarnya menjadi ibukota provinsi, sehingga akan berkembang pesat, baik dari segi pembangunan maupun aktivitas lainnya. Monitoring kondisi lingkungan, salah satunya logam berat di perairan perlu dilakukan sebagai rona awal lingkungan sebelum wilayah tersebut berkembang. Hal ini penting dilakukan mengingat sifat logam berat yang berubah toksik pada konsentrasi yang melebihi ambang batas. Tujuan kajian ini untuk mengidentifikasi potensi adanya kontaminasi logam berat pada wilayah pesisir Tanjung Selor, Kabupaten Bulungan, Provinsi Kalimantan Utara. Logam berat yang dikaji dibatasi pada air raksa $(\mathrm{Hg})$, kromium $(\mathrm{Cr})$, arsen (As), kadmium $(\mathrm{Cd})$, tembaga $(\mathrm{Cu})$, timbal $(\mathrm{Pb})$ dan seng $(\mathrm{Zn})$. Penentuan lokasi sampling dilakukan menggunakan citra Landsat 8 yang dirancang agar dapat mewakili kondisi kawasan pesisir tersebut. Sampel berasal dari air sumur, air sungai, air laut dan sedimen laut pada masing-masing empat, sembilan dan lima stasiun pengamatan. Sampel diambil pada bulan Agustus 2018 dengan metode grab sample (sampel sesaat) dan dianalisis kandungan logam beratnya menggunakan metode standar American Public Health Association (APHA) dengan instrumen Atomic Absorption Spectroscopy (AAS). Dari 23 sampel yang dihasilkan, hanya pada tiga stasiun pengamatan yang tidak terkontaminasi logam berat. Adapun pada 20 sampel lainnya ditemui satu hingga tiga jenis logam berat yang melebihi ambang batas. Secara umum $\mathrm{Cu}$ merupakan logam terbanyak yang terdeteksi melebihi ambang batas pada daerah kajian yang dijumpai di sampel air sungai, air laut, dan sedimen. $\mathrm{Zn}$ ditemui melebihi ambang batas pada air sumur. $\mathrm{Pb}$ dijumpai melebihi ambang batas pada sampel lima air sungai. Cd dijumpai melebihi ambang batas pada sampel air sungai, air laut dan sedimen. Sumber pencemaran diduga berasal dari aktivitas pertambangan batubara, kebun kelapa sawit dan sampah rumah tangga. Keseluruhan hasil kajian ini menunjukkan bahwa muara sungai cenderung mengakumulasi logam berat.
\end{abstract}

Kata Kunci: logam berat, ambang batas pencemaran, air sumur, air sungai, air laut, sedimen.

\begin{abstract}
Heavy Metal Contamination in the Coastal Area of Tanjung Selor North Kalimantan. The establishment of the North Kalimantan Province transformed the Tanjung Selor region and its surroundings into the provincial capital so that it will grow rapidly, both in terms of development and other activities. Monitoring environmental conditions, one of which is heavy metals in the waters need to be carried out as a starting environment before the area develops. This is important given the nature of heavy metals that change toxic at concentrations that exceed the threshold. The purpose of this study is to identify the potential for heavy metal contamination in the coastal area of Tanjung Selor, Bulungan Regency, North Kalimantan Province. Heavy metals studied is limiting to mercury (Hg), Chromium (Cr), Arsenic (As), Cadmium (Cd),
\end{abstract}


Copper $(\mathrm{Cu})$, Lead $(\mathrm{Pb})$ and Zinc $(\mathrm{Zn})$. The location of the sampling was carried out using Landsat 8 imagery designed to represent the condition of the coastal area. Samples come from well water, river water, seawater, and marine sediments at 4, 9 and 5 observation stations respectively. Samples were taken on August 2014 using the grab sample method and analyzed for heavy metal content using the standard American Public Health Association (APHA) method with the Atomic Absorption Spectroscopy (AAS) instrument. Of the 23 samples produced, only 3 observation stations were not contaminated with heavy metals. While in the other 20 samples one of three types of heavy metals were found that exceeded the threshold. In general, $\mathrm{Cu}$ is the most detected metal exceeding the threshold in the study area found in samples of river water, sea water and sediment. $\mathrm{Zn}$ is found to exceed the threshold in well water. $\mathrm{Pb}$ is found to exceed the threshold in sample 5 of river water. $\mathrm{Cd}$ is found to exceed the threshold in samples of river water, sea water and sediment. The source of pollution is thought to originate from coal mining activities, oil palm plantations, and household waste. The overall results of this study show that river estuaries tend to accumulate heavy metals.

Keywords: heavy metals, pollution threshold, well water, the river water, sea water, sediment.

\section{Pendahuluan}

Sumber daya air harus memenuhi kualitas sesuai dengan peruntukannya. Bagi keperluan manusia dan makhluk hidup lainnya, beberapa logam berat dapat menjadi mikronutrien esensial. Namun demikian, ada beberapa logam berat yang tidak diperlukan meskipun dalam jumlah kecil sekalipun, misalnya merkuri, kadmium, dan timbal. Logam berat walaupun termasuk mikronutrien penting namun dapat menjadi toksik jika berada dalam konsentrasi yang cukup tinggi (Mason 1993b). Oleh karena itu, monitoring mengenai konsentrasi logam berat mutlak harus dilakukan. Monitoring tersebut juga merupakan bagian penting dari rona awal lingkungan sebelum adanya kegiatan yang berpotensi mengubah kondisi lingkungan tersebut (BPMigas 2011). Hasil monitoring tersebut harus menjadi perhatian dan perlu ditindaklanjuti dalam mencegah pencemaran lingkungan.

Keberadaan logam berat di lingkungan dapat disebabkan oleh faktor alam dan aktivitas manusia. Tingginya konsentrasi logam berat di perairan secara alami dapat terjadi akibat pencucian batuan, deposisi atmosfer, drainase dan limpasan dari sungai. Deposisi atmosfer merupakan perubahan zat gas dari atmosfer menjadi zat padat yang kemudian tertransportasi ke perairan. Deposisi dari atmosfer diakui sebagai penyumbang utama kontaminan sebagai sumber pencemaran laut. Bahkan sudah terbukti bahwa melalui deposisi atmosfir dan transpor biologis, berbagai polutan kemudian dapat mencapai wilayah lautan yang jauh dari titik produksi atau asal pembuangannya (Atlas \& Giam 1981).

Aktivitas manusia yang dapat menyebabkan pencemaran logam berat di perairan terjadi akibat pembuangan limbah dari masyarakat perkotaan, industri dan pertambangan (Singovszka et al. 2014). Logam berat tersebut kemudian tertransportasi melalui udara, air dan mengendap dalam sedimen atau tanah sehingga menjadi limbah berbahaya (Dean et al. 1972). Konsentrasi logam berat di air sungai akan dapat meningkat beberapa ribu kali akibat limbah pertambangan (Forstner \& Wittman 1981).

Pencemaran di perairan ditentukan oleh konsentrasi unsur dan atau senyawa kimia yang terkandung dalam ekosistem tersebut. Sebagai contoh berikut disampaikan kategori kelompok pencemar secara kimia yang dapat menyebabkan turunnya kualitas air sungai, yaitu :

- Senyawa organik terurai seperti karbohidrat, protein, sukrosa, glukosa, dan lemak; senyawa organik sulit terurai seperti pestisida, herbisida, deterjen, minyak, dan oli;

- Senyawa nutrien seperti pupuk, senyawa pospat, dan senyawa nitrogen;

- Senyawa terapung terdiri dari berbagai jenis cairan atau padatan yang berat jenisnya lebih rendah dari air sehingga mengambang di permukaan air;

- Senyawa logam yang mengandung logam berat, seperti raksa $(\mathrm{Hg})$, kadmium (Cd), dan krom (Cr) dan lainnya;

- Senyawa anorganik terlarut terdiri dari berbagai senyawa kimia terlarut yang mengandung unsur anorganik, seperti kalsium $(\mathrm{Ca})$, magnesium $(\mathrm{Mg})$, dan sianida $(\mathrm{CN})$;

- Senyawa asam/basa (acid/alkali) terdiri dari senyawa asam atau senyawa basa, seperti asam sulfat $\left(\mathrm{H}_{2} \mathrm{SO}_{4}\right)$, kapur $(\mathrm{CaO})$, dan soda kostik $(\mathrm{NaOH})$ (Siregar 2005).

Dalam pemantauan kondisi perairan, Mason (1993a) mengategorikan bahwa aktivitas monitoring kualitas perairan memiliki tujuan untuk: 
- Environmental surveillance, yakni untuk mendeteksi dan mengukur pengaruh yang ditimbulkan oleh suatu pencemar terhadap kualitas lingkungan dan mengetahui perbaikan kualitas lingkungan yang setelah pencemar tersebut dihilangkan;

- Establishing water-quality criteria, untuk mengetahui hubungan sebab akibat antara perubahan variabel-variabel ekologi perairan dengan parameter fisika dan kimia untuk mendapatkan baku mutu kualitas air; dan

- Appraisal of resources, untuk mengetahui gambaran kualitas air secara umum.

Kajian ini merupakan suatu appraisal of resources mengenai keberadaan logam berat di perairan Tanjung Selor dan sekitarnya. Tujuannya untuk mengidentifikasi potensi adanya kontaminasi logam berat di kawasan pesisir Tanjung Selor dan sekitarnya, Kabupaten Bulungan, Provinsi Kalimantan Utara. Adanya kegiatan penduduk Tanjung Selor baik di sektor pertanian, pertambangan dan aktivitas lainnya dimungkinkan menyebabkan terjadinya perubahan lingkungan dan pencemaran. Selain berdampak positif, aktivitas tersebut bisa menyebabkan pencemaran udara, tanah dan air pada wilayah tersebut.

Pada kajian ini konsentrasi logam berat yang dianalisis meliputi air raksa $(\mathrm{Hg})$, kromium $(\mathrm{Cr})$, arsen (As), kadmium $(\mathrm{Cd})$, tembaga $(\mathrm{Cu})$, timbal $(\mathrm{Pb})$ dan seng ( $\mathrm{Zn})$. Pertimbangan pemilihan logam berat tersebut terutama berdasarkan sifat toksiknya, peranannya sebagai trace element yang bersifat esensial dan nonesensial dan indikasi adanya sumber-sumber pencemar di wilayah tersebut. Walaupun pada dasarnya semua logam berat tersebut baik yang nonesensial maupun esensial dapat bersifat toksik, apabila terjadi peningkatan kadarnya di dalam perairan (Sanusi 2006). Logam berat yang sifat toksik yang tinggi seperti $\mathrm{Hg}, \mathrm{Cd}, \mathrm{Pb}, \mathrm{Cu}$ dan $\mathrm{Zn}$; dan yang bersifat toksik sedang, seperti $\mathrm{Cr}$ (Moore \& Ramamoorthy 1984). Adapun logam berat yang bersifat esensial seperti $\mathrm{Cr}, \mathrm{Cu}$ dan $\mathrm{Zn}$, sedangkan yang bersifat nonesensial seperti As, $\mathrm{Cd}, \mathrm{Pb}$, dan Hg (Sanusi 2006).

Tanjung Selor terletak di Kabupaten Bulungan dan merupakan ibukota Provinsi Kalimantan Utara. Provinsi tersebut merupakan hasil pemekaran dari Provinsi Kalimantan Timur melalui Undang-Undang Nomor 20 Tahun 2012. Penduduk Tanjung Selor sekitar 57.160 jiwa dengan kepadatan 45 jiwa $/ \mathrm{km}^{2}$ merupakan daerah terpadat di kawasan ini. Tanjung Selor terletak di tepian Sungai Kayan yang kemudian bercabang menjadi beberapa sungai ke arah muara. Sungaisungai tersebut antara lain Sungai Ubanangka, Sungai Kubil, Sungai Sabanar, Sungai Bulungan, Sungai Temenggah dan sungai kecil lainnya. Pada muara sungai terdapat 19 pulau dengan tujuh diantaranya tanpa nama (Suhelmi \& Ramdhan 2014). Sungai-sungai tersebut dimanfaatkan oleh penduduk sebagai sarana transportasi ke berbagai kawasan, sebagai sumber air bersih dan kebutuhan sehari-hari penduduk untuk mandi, cuci, untuk kegiatan pertanian, budidaya ikan di tambak maupun lainnya.

\section{Metodologi}

Perencanaan lokasi pengambilan sampel dilakukan dengan menggunakan citra Landsat 8. Citra yang digunakan terdiri dari dua scenes, yaitu path/row 117/58 dan 116/58 dari tahun 2014. Perencanaan ini dilakukan dengan mengidentifikasi sebaran Sungai Kayan dari Kota Tanjung Selor ke arah muara beserta letak dari permukiman penduduk. Koordinat dan lokasi pengambilan sampel dari air sumur penduduk, air sungai, dan air laut dan sedimennya dapat dilihat pada Gambar 1. Pengambilan sampel air sungai dilakukan di pusat-pusat permukiman yang dekat dengan sungai yang dapat mewakili bagian sungai, kedekatan dengan lokasi pemukiman, area tambang batubara, perkebunan kelapa sawit dan sumur migas tua (Tabel 1).

Pengambilan air sungai dimulai pada hulu sungai dengan permukiman jarang penduduk (Sg2) sebelum kota Tanjung Selor, kemudian ke arah utara mengikuti sungai utama sampai titik sampel L5. Survei selanjutnya ke selatan lokasi kajian sampai titik sampel L2 dan alur selanjutnya pengambilan sampel titik Sg5 kemudian diakhiri pada stasiun L3. Pada wilayah laut pengambilan sampel dilakukan di dekat muara sungai utama dan satu lokasi ke arah laut lepas sebagai pembanding.

Pengambilan sampel air dan sedimen dilakukan dengan metode grab sample, yaitu dengan mengambil sampel air secara langsung untuk mencerminkan kondisi sesaat dari badan air (Effendi 2012; O’Neill \& Kerr 2004). Pengambilan sampel air dan sedimen dilakukan pada bulan Agustus 2014 berjumlah 23 sampel. Sampel ini terdiri dari sembilan sampel air sungai, empat sampel air sumur penduduk, lima sampel air laut dan lima sampel sedimen. Pengambilan sedimen dilakukan menggunakan grab sampler kecil (Van Veen Grab). Parameter logam berat yang diukur adalah air raksa $(\mathrm{Hg})$, kromium $(\mathrm{Cr})$, arsen $(\mathrm{As})$, kadmium $(\mathrm{Cd})$, tembaga $(\mathrm{Cu})$, timbal $(\mathrm{Pb})$ dan seng $(\mathrm{Zn})$. Metode analisis laboratorium 
untuk penentuan konsentrasi logam berat menggunakan metode standar American Public Health Association (APHA) dengan instrumen Atomic Absorption Spectroscopy (AAS) dengan batas deteksi/detection limit sebagai berikut (Tabel 2). Ada tiga metode yang digunakan dalam menganalisis logam berat tersebut, yaitu (1) analisis $\mathrm{Hg}$ dengan APHA ed. 22nd, 2012 bagian 3112-B menggunakan metode Cold Vapor Fumeless Atomic Absorption Spectrometer (AAS); (2) analisis Cr dengan APHA ed. 22, 2012 bagian 3500-Cr-B menggunakan metode Atomic Absorption untuk total $\mathrm{Cr}$; dan (3) analisis As, Cd, $\mathrm{Cu}, \mathrm{Pb}$, dan $\mathrm{Zn}$ dengan APHA ed. 22, 2012 bagian 3111-B menggunakan metode Direct AirAcetylene Flame.

Hasil analisis konsentrasi logam berat kemudian dibandingkan dengan baku mutu logam berat di air (Tabel 3) dan sedimen (Tabel 4 dan
Tabel 5) yang berlaku. Analisis kandungan logam berat juga diinterpertasikan berdasarkan peta tata guna lahan yang diolah dari citra Landsat 8 yang dapat menggambarkan aktivitas antropogenik. Hal ini penting karena selain faktor alam, konsentrasi logam berat akan juga dipengaruhi juga oleh aktivitas manusia, misal: limbah domestik, industri dan pertambangan (Singovszka et al. 2014).

Nilai di bawah TEL (threshold effect levels) merupakan rentang efek minimal yang menyebabkan efek samping jarang terjadi. Nilai antara TEL dan PEL (probable effect levels) adalah berbagai efek yang mungkin terjadi yang menyebabkan efek kadang-kadang merugikan. Nilai di atas PEL adalah rentang efek yang mungkin terjadi yang mengakibatkan efek samping sering terjadi.

Tabel 1. Karakteristik lokasi pengambilan sampel.

Table 1. Consideration and characteristics of sampling location.

\begin{tabular}{|c|c|c|}
\hline No & Sampley & Characteristics of sampling location \\
\hline 1. & $\begin{array}{l}\text { River } \\
\text { water }\end{array}$ & $\begin{array}{l}\text { The main river and its branches flow throughout the year. The sampling location is } \\
\text { prioritized near settlements, mining, oil palm plantations and abandon oil and gas wells. } \\
\text { The temperature of sampling ranged from } 26.10 \mathrm{C} \text { to } 31.10^{\circ} \mathrm{C} \\
\text { The river water color is generally tawny } \\
\text { Flowing river } \\
\text { The pH between } 6.77 \text { to } 8.01 \\
\text { The location of } \mathrm{Sg} 1 \text { dan } \mathrm{Sg} 9 \text { near abandon oils well and bare soil } \\
\mathrm{Sg} 2 \text { near settlements } \\
\mathrm{Sg} 3 \text { near settlements and plantation } \\
\mathrm{Sg} 4 \text {, Sg5 and Sg } 8 \text { near fishpond in river delta } \\
\mathrm{Sg} 6 \text { near abandon oil well, plantation and coal mining } \\
\mathrm{Sg} 7 \text { near fishpond with upstream is mining and plantation }\end{array}$ \\
\hline 2. & $\begin{array}{l}\text { Well } \\
\text { water }\end{array}$ & $\begin{array}{l}\text { In the center of the settlements that are crossed by rivers that flow throughout the year } \\
\text { Generally well water is not smelly and tasteless } \\
\text { Well water color tend a yellowish to tawny with a color index }<1 \text { Pt.Co up to } 295 \text { Pt.Co } \\
\text { Temperature range is } 27.3^{0} \mathrm{C} \text { up to } 28.8^{0} \mathrm{C}\end{array}$ \\
\hline 3. & $\begin{array}{l}\text { Sea } \\
\text { water }\end{array}$ & $\begin{array}{l}\text { Near the mouth of the river, it is assumed that heavy metal conditions are affected by river } \\
\text { flow and } 1 \text { location as a comparison to the open sea } \\
\text { no trash and oil layer found } \\
\text { Temperature range is } 27.3^{\circ} \mathrm{C} \text { up to } 30.9^{\circ} \mathrm{C} \text {, } \\
\text { The water sample is turbid }\end{array}$ \\
\hline
\end{tabular}


Tabel 2. Batas deteksi (DL) untuk sampel air dan sedimen.

Table 2. Detection limit (DL) for water and sediment sample.

\begin{tabular}{|c|c|c|c|c|c|}
\hline \multirow[b]{2}{*}{ Parameters } & \multicolumn{2}{|c|}{ Water sample } & \multicolumn{2}{|c|}{ Sediment sampel } & \multirow[b]{2}{*}{ Method/instrument } \\
\hline & Unit & Detection limit & Unit & $\begin{array}{c}\text { Detection } \\
\text { limit }\end{array}$ & \\
\hline $\mathrm{Hg}$ & $\mu \mathrm{g} / \mathrm{L}$ & 0.02 & $\mathrm{mg} / \mathrm{kg}$ & 0.0002 & APHA, ed. 22, 2012, 3112-B \\
\hline $\mathrm{Cr}$ & $\mathrm{mg} / \mathrm{L}$ & 0.001 & $\mathrm{mg} / \mathrm{kg}$ & 0.001 & APHA, ed. 22, 2012, 3500-Cr-B \\
\hline As & $\mu \mathrm{g} / \mathrm{L}$ & 0.02 & $\mathrm{mg} / \mathrm{kg}$ & 0.0002 & APHA, ed. 22, 2012, 3113-B \\
\hline $\mathrm{Cd}$ & $\mathrm{mg} / \mathrm{L}$ & 0.001 & $\mathrm{mg} / \mathrm{kg}$ & 0.001 & APHA, ed. 22, 2012, 3111-B \\
\hline $\mathrm{Cu}$ & $\mathrm{mg} / \mathrm{L}$ & 0.002 & $\mathrm{mg} / \mathrm{kg}$ & 0.002 & APHA, ed. 22, 2012, 3111-B \\
\hline $\mathrm{Pb}$ & $\mathrm{mg} / \mathrm{L}$ & 0.002 & $\mathrm{mg} / \mathrm{kg}$ & 0.002 & APHA, ed. 22, 2012, 3111-B \\
\hline $\mathrm{Zn}$ & $\mathrm{mg} / \mathrm{L}$ & 0.002 & $\mathrm{mg} / \mathrm{kg}$ & 0.002 & APHA, ed. 22, 2012, 3111-B \\
\hline
\end{tabular}

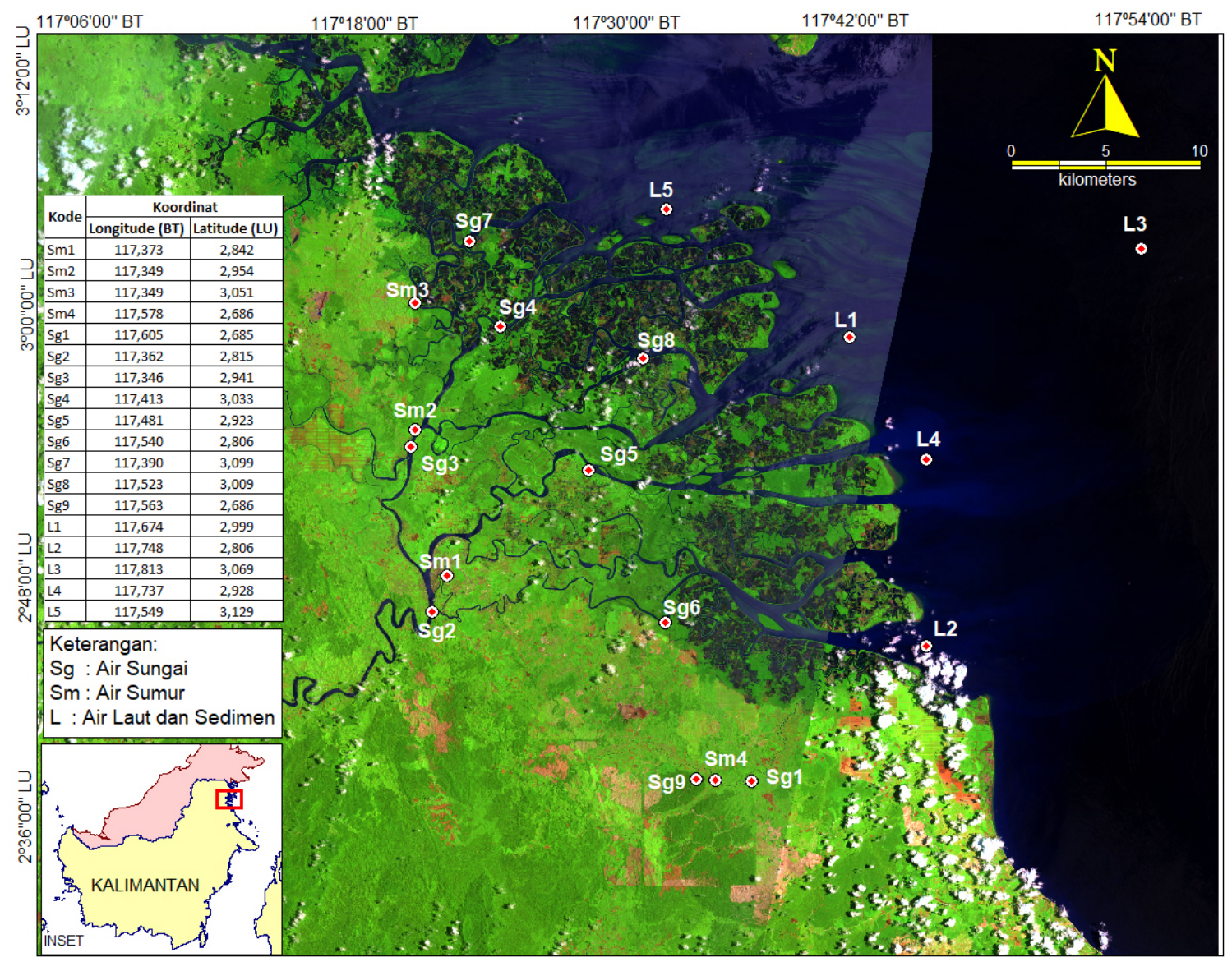

Gambar 1. Lokasi pengambilan sampel air dan sedimen.

Figure 1. Location of collection water and sediment sample. 
Tabel 3. Baku mutu logam berat di perairan.

Table 3 . The quality standard of heavy metals in waters.

\begin{tabular}{|c|c|c|c|c|c|c|c|}
\hline \multirow{3}{*}{ No. } & \multirow{3}{*}{ Parameters (mg/l) } & \multicolumn{4}{|c|}{ River water quality standards $*$ ) } & \multirow{3}{*}{$\begin{array}{c}\text { Well water } \\
\text { quality standard } \\
* *)\end{array}$} & \multirow{3}{*}{$\begin{array}{c}\text { Seawater } \\
\text { quality } \\
\text { standards } \\
* * *)\end{array}$} \\
\hline & & \multicolumn{4}{|c|}{ Class } & & \\
\hline & & I & II & III & IV & & \\
\hline 1 & Mercury (Hg) & 0.001 & 0.002 & 0.002 & 0.005 & 0.001 & 0.001 \\
\hline 2 & Chromium (Cr) & 0.05 & 0.05 & 0.05 & 1 & 0.05 & 0.005 \\
\hline 3 & Arsenic (As) & 0.05 & 1 & 1 & 1 & 0.05 & 0.012 \\
\hline 4 & Cadmium $(\mathrm{Cd})$ & 0.01 & 0.01 & 0.01 & 0.01 & 0.005 & 0.001 \\
\hline 5 & Copper $(\mathrm{Cu})$ & 0.02 & 0.02 & 0.02 & 0.2 & 1.000 & 0.008 \\
\hline 6 & Lead $(\mathrm{Pb})$ & 0.03 & 0.03 & 0.03 & 1 & 0.05 & 0.008 \\
\hline 7 & Zinc $(\mathrm{Zn})$ & 0.05 & 0.05 & 0.05 & 2 & 5 & 0.05 \\
\hline
\end{tabular}

*) Quality standards, according to Republic of Indonesia Government Regulation Number 82 of 2001 concerning management of water quality and water pollution control

**) Quality standards, according to regulation of the Minister of Health of the Republic of Indonesia. No.416 / MENKES / PER / IX / 1990 (Appendix II, Requirements for Quality of Drinking Water)

***) Quality standards, according to Decree of state Minister of Environmental affairs of the Republic of Indonesia. Decree 51 of 2004 Attachment III (for marine biota)

Tabel 4. Baku mutu logam berat pada sedimen ( $\mathrm{mg} / \mathrm{kg}$, berat kering), menurut Swedish Enviromental Protection Agency (SEPA 2002).

Table 4. The quality standard of heavy metal in sediment ( $\mathrm{mg} / \mathrm{kg}$, dry weight), according to Swedish Enviromental Protection Agency (SEPA 2002).

\begin{tabular}{|c|c|c|c|c|c|}
\hline Heavy metals & $\begin{array}{l}\text { Class } 1 \\
\text { None/Insignificant }\end{array}$ & $\begin{array}{l}\text { Class } 2 \\
\text { Slight }\end{array}$ & $\begin{array}{l}\text { Class } 3 \\
\text { Significant }\end{array}$ & $\begin{array}{l}\text { Class } 4 \\
\text { Large }\end{array}$ & $\begin{array}{l}\text { Class } 5 \\
\text { Very large }\end{array}$ \\
\hline Arsenic (As) & $<10$ & $10-17$ & $17-28$ & $28-45$ & $>45$ \\
\hline Cadmium (Cd) & $<0,2$ & $0,2-0,5$ & $0,5-1,2$ & $1,2-3$ & $>3$ \\
\hline Cobalt (Co) & $<12$ & $12-20,4$ & $20,4-34,8$ & $34,8-60$ & $>60$ \\
\hline Chromium (Cr) & $<40$ & $40-48$ & $48-60$ & $60-72$ & $>72$ \\
\hline Copper $(\mathrm{Cu})$ & $<15$ & $15-30$ & $30-49,5$ & $49,5-79,5$ & $>79,5$ \\
\hline Mercury (Hg) & $<0,04$ & $0,04-0,12$ & $0,12-0,4$ & $0,4-1$ & $>1$ \\
\hline Nickel (Ni) & $<30$ & $30-45$ & $45-66$ & $66-99$ & $>99$ \\
\hline Lead $(\mathrm{Pb})$ & $<25$ & $25-40$ & $40-65$ & $65-110$ & $>110$ \\
\hline Zinc Zn) & $<85$ & $85-127,5$ & $127,5-204$ & $204-357$ & $>357$ \\
\hline
\end{tabular}

Tabel 5. Baku mutu logam berat pada sedimen (mg/kg, berat kering) (CCME 2001).

Table 5. The quality standard of heavy metal in sediment $(\mathrm{mg} / \mathrm{kg}$, dry weight), according to Canadian Council of Ministers of the Environment (CCME 2001).

\begin{tabular}{lll} 
Heavy metals & ISQG/TEL & PEL \\
\hline Arsenic $(\mathrm{As})$ & 7,24 & 41,6 \\
Cadmium $(\mathrm{Cd})$ & 0,7 & 4,2 \\
Chromium $(\mathrm{Cr})$ & 52,3 & 160 \\
Copper $(\mathrm{Cu})$ & 18,7 & 108 \\
Mercury $(\mathrm{Hg})$ & 0,13 & 0,7 \\
Lead $(\mathrm{Pb})$ & 30,2 & 112 \\
Zinc $(\mathrm{Zn})$ & 124 & 271 \\
\hline
\end{tabular}




\section{Hasil}

\section{Konsentrasi Logam Berat pada Air Sumur}

Hasil pengukuran logam berat di air sumur menunjukkan konsentrasi $\mathrm{Cu}, \mathrm{Hg}, \mathrm{Cr}$ dan $\mathrm{Cd}$ tidak terdeteksi. Adapun konsentrasi logam lainnya adalah sebagai berikut : As berkisar $0,0002-0,0003 \mathrm{mg} / \mathrm{L}, \mathrm{Pb}$ berkisar $<0,002-0,047$ $\mathrm{mg} / \mathrm{L}$, serta $\mathrm{Zn}$ mempunyai rentang konsentrasi $<0,002-0,09 \mathrm{mg} / \mathrm{L}$. Hasil ini menunjukkan bahwa tidak ditemui kontaminasi logam $\mathrm{Hg}, \mathrm{Cr}$, $\mathrm{As}, \mathrm{Cd}, \mathrm{Cu}$ dan $\mathrm{Pb}$ di air sumur. Adapun kontaminasi $\mathrm{Zn}$ ditemukan di stasiun $\mathrm{Sm} 3$ dan stasiun Sm1. Keseluruhan kandungan logam berat pada air sumur dapat dilihat pada Tabel 6 .

\section{Konsentrasi Logam Berat pada Air Sungai}

Hasil analisis laboratorium logam berat pada air sungai menunjukkan bahwa konsentrasi $\mathrm{Hg}, \mathrm{Cr}$ dan $\mathrm{Zn}$ tidak terdeteksi, sedangkan $\mathrm{Cd}$ tidak terdeteksi kecuali pada stasiun $\mathrm{Sg} 7$, As mempunyai konsentrasi berkisar 0,163 - 0,435 $\mu \mathrm{g} / \mathrm{L}, \mathrm{Cu}$ mempunyai konsentrasi berkisar 0,014 $0,041 \mathrm{mg} / \mathrm{L}$ dan $\mathrm{Pb}$ mempunyai konsentrasi berkisar $<0,002-0,109 \mathrm{mg} / \mathrm{L}$.

Beberapa konsentrasi logam berat sudah melewati ambang batas, diantaranya $\mathrm{Cu}$ dan $\mathrm{Pb}$, serta $\mathrm{Cd}$ hanya di stasiun $\mathrm{Sg} 7$. Konsentrasi $\mathrm{Cu}$ yang melebihi ambang batas ditemukan di 7 stasiun dengan nilai tertinggi di stasiun $\mathrm{Sg}$ 7. Konsentrasi $\mathrm{Pb}$ yang melewati melebihi ambang batas ditemukan pada lima stasiun, konsentrasi tertinggi di stasiun $\mathrm{Sg} 7$. Adapun konsentrasi logam berat pada air sungai dapat dilihat pada Tabel 7.

\section{Konsentrasi Logam Berat di Laut}

Konsentrasi logam berat di laut dibedakan menjadi dua bagian, yaitu logam berat di air dan di sedimen. Hasil analisis air laut menunjukkan bahwa konsentrasi $\mathrm{Hg}$ dan $\mathrm{Cr}$ tidak terdeteksi. Konsentrasi As berkisar 02,139 - 0,228 $\mu \mathrm{g} / \mathrm{L}, \mathrm{Cd}$ berkisar 0,007 - 0,009 mg/L, Pb berkisar 0,002$0,007 \mathrm{mg} / \mathrm{L}, \quad \mathrm{Zn}$ berkisar $0,09-0,011 \mathrm{mg} / \mathrm{L}$ dan $\mathrm{Cu}$ berkisar 0,008 - 0,009 mg/L (Tabel 8).
Konsentrasi logam berat $\mathrm{Cr}$, As, $\mathrm{Zn}, \mathrm{Hg}$ dan $\mathrm{Pb}$ di air laut masih di bawah baku mutu yang telah ditetapkan oleh KepMen LH No 51 tahun 2004 untuk biota laut. Hal ini berbeda dengan bagian hulu sungai yang di beberapa sampel air sungai ditemukan konsentrasi $\mathrm{Pb}$ melebihi ambang batas yang ditetapkan. Konsentrasi $\mathrm{Cd}$ dalam air laut ditemukan sudah melewati ambang batas baku mutu yang ditetapkan di lima stasiun dan konsentrasi $\mathrm{Cu}$ di dua stasiun.

Tabel 9 menyajikan hasil analisis laboratorium untuk sampel sedimen laut. Hasil tersebut menunjukkan bahwa konsentrasi $\mathrm{Hg}$ dan As tidak terdeteksi, Cr berkisar 4,29- 6,27 mg/kg, $\mathrm{Pb}$ berkisar 1,28 - 2,18 mg/kg, Cu berkisar 15,20$23,17 \mathrm{mg} / \mathrm{kg}, \mathrm{Zn}$ berkisar 19,28 - 25,18 mg/kg dan Cd berkisar 0,89-1,76 mg/kg.

Konsentrasi $\mathrm{Cr}$, $\mathrm{As}, \mathrm{Zn}, \mathrm{Hg}$, dan $\mathrm{Pb}$ menurut SEPA (2002) dan CCME (2001) masih di bawah ambang batas baku mutu, sedangkan konsentrasi $\mathrm{Cd}$ menunjukkan sudah di atas ambang batas baku mutu kelas III (SEPA 2002) dan telah melebihi TEL (CCME 2001) di semua stasiun. Logam berat $\mathrm{Cu}$ melebihi ambang batas kelas II (ringan) di semua stasiun (SEPA 2002) dan telah melebihi TEL (CCME 2001) pada stasiun L4 dan L5. Kedua stasiun tersebut dapat disimpulkan paling tercemar dibandingkan dua stasiun lainnya. Efek merugikan kadang-kadang dapat terjadi akibat kontaminasi $\mathrm{Cu}$ dan juga $\mathrm{Cd}$.

Adapun peta sebaran lokasi dan penggunaan lahan disajikan pada Gambar 2 untuk menggambarkan sebaran lokasi yang tercemar dan mendeteksi kemungkinan sumber pencemar. Penggunaan lahan yang terdapat di area kajian antara lain adalah sungai dan tubuh air, hutan bakau primer, hutan rawa primer, hutan sekunder, lahan kering tidak produktif, permukiman, pertambangan (batubara), pertanian lahan kering, bertanian lahan kering bercampur dengan semak, tambak dan tanah terbuka serta titik lokasi bekas sumur pengeboran. Peta tersebut disajikan bersama titik-titik sampel untuk mengaitkan titik lokasi yang tercemar dengan penggunaan lahannya. 
Tabel 6. Konsentrasi logam berat pada air sumur dibandingkan dengan baku mutu .

Table 6 . Heavy metal concentration in well water corresponding to quality standard

\begin{tabular}{cccccccc}
\hline & & \multicolumn{7}{c}{ Parameters } \\
& $\mathrm{Hg}$ & $\mathrm{Cr}$ & $\mathrm{As}$ & $\mathrm{Cd}$ & $\mathrm{Cu}$ & $\mathrm{Pb}$ & $\begin{array}{c}\mathrm{Zn} \\
\mathrm{mg} / \mathrm{L}\end{array}$ \\
\hline Stations & $\mu \mathrm{g} / \mathrm{L}$ & $\mathrm{mg} / \mathrm{L}$ & $\mu \mathrm{g} / \mathrm{L}$ & $\mathrm{mg} / \mathrm{L}$ & $\mathrm{mg} / \mathrm{L}$ & $\mathrm{mg} / \mathrm{L}$ & 0.005 \\
$\mathrm{Sm} 1$ & $<0.020$ & $<0.001$ & 0.267 & $<0.001$ & $<0.002$ & $<0.002$ & 0.002 \\
$\mathrm{Sm} 2$ & $<0.020$ & $<0.001$ & 0.247 & $<0.001$ & $<0.002$ & $<0.002$ & $<0.002$ \\
$\mathrm{Sm} 3$ & $<0.20$ & $<0.001$ & 0.276 & $<0.001$ & $<0.002$ & 0.022 & 0.09 \\
$\mathrm{Sm} 4$ & $<0.20$ & $<0.001$ & 0.376 & $<0.001$ & $<0.002$ & 0.047 & 0.016 \\
\hline
\end{tabular}

* Quality standards, according to regulation of the Minister of Health of the Republic of Indonesia. No.416 / MENKES / PER / IX / 1990 (Appendix II, Requirements for Quality of Drinking Water)

Tabel 7. Konsentrasi logam berat pada air sungai dibandingkan dengan baku mutu.

Table 7 . Heavy metal concentration in river corresponding to quality standard.

\begin{tabular}{cccccccc}
\hline & \multicolumn{7}{c}{ Parameters } \\
Stations & $\mathrm{Hg}$ & $\mathrm{Cr}$ & $\mathrm{As}$ & $\mathrm{Cd}$ & $\mathrm{Cu}$ & $\mathrm{Pb}$ & $\mathrm{Zn}$ \\
& $\mu \mathrm{g} / \mathrm{L}$ & $\mathrm{mg} / \mathrm{L}$ & $\mu \mathrm{g} / \mathrm{L}$ & $\mathrm{mg} / \mathrm{L}$ & $\mathrm{mg} / \mathrm{L}$ & $\mathrm{mg} / \mathrm{L}$ & $\mathrm{mg} / \mathrm{L}$ \\
\hline $\mathrm{Sg} 1$ & $<0.020$ & $<0.001$ & 0.163 & $<0.001$ & 0.014 & $\mathbf{0 . 0 5 3}$ & $<0.002$ \\
$\mathrm{Sg} 2$ & $<0.020$ & $<0.001$ & 0.267 & $<0.001$ & $\mathbf{0 . 0 2 2}$ & 0.004 & $<0.002$ \\
$\mathrm{Sg} 3$ & $<0.020$ & $<0.001$ & 0.241 & $<0.001$ & 0.016 & 0.025 & $<0.002$ \\
$\mathrm{Sg} 4$ & $<0.020$ & $<0.001$ & 0.240 & $<0.001$ & $\mathbf{0 . 0 2 8}$ & $\mathbf{0 . 0 3 7}$ & $<0.002$ \\
$\mathrm{Sg} 5$ & $<0.020$ & $<0.001$ & 0.335 & $<0.001$ & $\mathbf{0 . 0 4 1}$ & $<0.002$ & $<0.002$ \\
$\mathrm{Sg} 6$ & $<0.020$ & $<0.001$ & 0.255 & $<0.001$ & $\mathbf{0 . 0 2 7}$ & $\mathbf{0 . 0 9 3}$ & $<0.002$ \\
$\mathrm{Sg} 7$ & $<0.020$ & $<0.001$ & 0.196 & $\mathbf{0 . 0 1 6}$ & $\mathbf{0 . 0 5 7}$ & $\mathbf{0 . 1 0 9}$ & $<0.002$ \\
$\mathrm{Sg} 8$ & $<0.020$ & $<0.001$ & 0.223 & $<0.001$ & $\mathbf{0 . 0 3 6}$ & 0.027 & $<0.002$ \\
$\mathrm{Sg} 9$ & $<0.020$ & $<0.001$ & 0.435 & $<0.001$ & $\mathbf{0 . 0 3 0}$ & $\mathbf{0 . 0 6 1}$ & $<0.002$ \\
\hline
\end{tabular}

* Quality standards, according to Republic of Indonesia Government Regulation Number 82 of 2001 concerning management of water quality and water pollution control

Tabel 8. Konsentrasi logam berat pada air laut dibandingkan dengan baku mutu.

Table 8 . Heavy metal concentration in sea water corresponding to quality standard.

\begin{tabular}{cccccccc}
\hline & \multicolumn{7}{c}{ Parameter } \\
& $\mathrm{Hg}$ & $\mathrm{Cr}$ & $\mathrm{As}$ & $\mathrm{Cd}$ & $\mathrm{Cu}$ & $\mathrm{Pb}$ & $\mathrm{Zn}$ \\
Stations & $\mu \mathrm{g} / \mathrm{L}$ & $\mathrm{mg} / \mathrm{L}$ & $\mu \mathrm{g} / \mathrm{L}$ & $\mathrm{mg} / \mathrm{L}$ & $\mathrm{mg} / \mathrm{L}$ & $\mathrm{mg} / \mathrm{L}$ & $\mathrm{mg} / \mathrm{L}$ \\
\hline $\mathrm{L} 1$ & $<0.020$ & $<0.001$ & 0.139 & $\mathbf{0 . 0 0 9}$ & $\mathbf{0 . 0 0 9}$ & 0.007 & 0.011 \\
$\mathrm{~L} 2$ & $<0.020$ & $<0.001$ & 0.228 & $\mathbf{0 . 0 0 8}$ & 0.008 & 0.004 & 0.009 \\
$\mathrm{~L} 3$ & $<0.020$ & $<0.001$ & 0.180 & $\mathbf{0 . 0 0 8}$ & 0.008 & 0.002 & 0.009 \\
$\mathrm{~L} 4$ & $<0.020$ & $<0.001$ & 0.183 & $\mathbf{0 . 0 0 8}$ & 0.008 & 0.003 & 0.010 \\
$\mathrm{~L} 5$ & $<0.020$ & $<0.001$ & 0.197 & $\mathbf{0 . 0 0 7}$ & $\mathbf{0 . 0 0 9}$ & 0.003 & 0.011 \\
\hline
\end{tabular}

* Quality standards, according to Decree of state Minister of Environmental affairs of the Republic of Indonesia. Decree 51 of 2004 Attachment III (for marine biota)

Tabel 9. Konsentrasi logam berat pada sedimen dibandingkan dengan baku mutu.

Table 9. Heavy metal concentration in sediment corresponding to quality standard.

\begin{tabular}{lccccccc}
\hline & \multicolumn{7}{c}{ Parameters $(\mathrm{mg} / \mathrm{kg})$} \\
Stations & $\mathrm{Hg}$ & $\mathrm{Cr}$ & $\mathrm{As}$ & $\mathrm{Cd}$ & $\mathrm{Cu}$ & $\mathrm{Pb}$ & $\mathrm{Zn}$ \\
\hline L1 & $<0.0002$ & 4.38 & $<0.0002$ & $\mathbf{0 . 8 6}$ & $\mathbf{1 5 . 2 0}$ & 1.29 & 21.63 \\
L2 & $<0.0002$ & 4.29 & $<0.0002$ & $\mathbf{0 . 9 2}$ & $\mathbf{1 6 . 2 8}$ & 1.54 & 22.12 \\
L3 & $<0.0002$ & 5.18 & $<0.0002$ & $\mathbf{1 . 2 7}$ & $\mathbf{1 8 . 2 9}$ & 2.18 & 25.18 \\
L4 & $<0.0002$ & 6.27 & $<0.0002$ & $\mathbf{1 . 7 6}$ & $\mathbf{1 9 . 3 5}$ & 1.65 & 19.28 \\
L5 & $<0.0002$ & 5.40 & $<0.0002$ & $\mathbf{1 . 4 0}$ & $\mathbf{2 3 . 1 7}$ & 1.28 & 21.28 \\
\hline
\end{tabular}

The quality standard of heavy metal in sediment (SEPA, $2002 \&$ CCME, 2001) 
Oseanologi dan Limnologi di Indonesia 2019 4(1):1-14

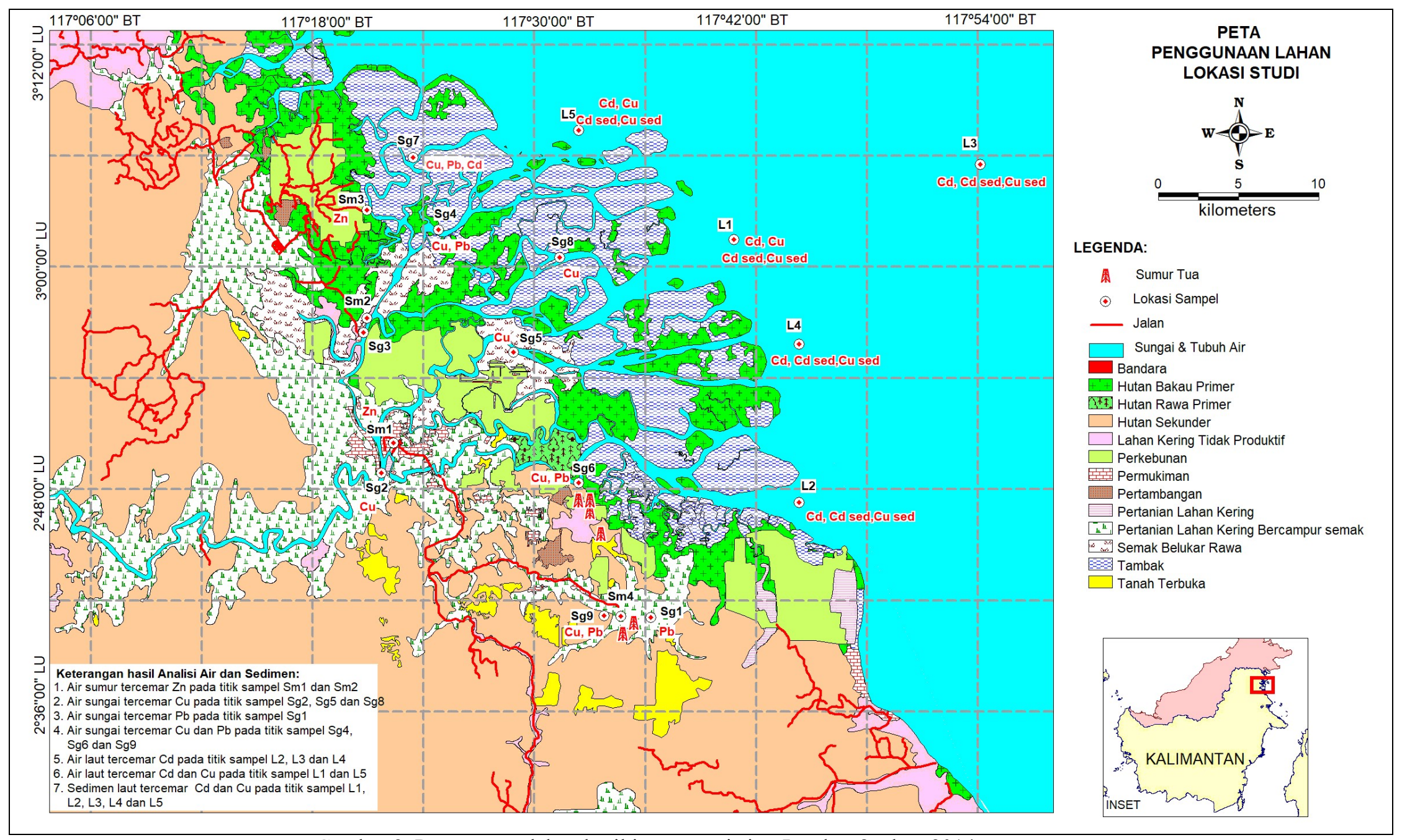

Gambar 2. Penggunaan lahan hasil interpretasi citra Landsat 8 tahun 2014.

Figure 2. Land use was interpretated from Landsat 8 year 2014. 


\section{Pembahasan}

Aktivitas tambang terbuka, terutama seperti tambang batubara dan emas baik bekas tambang ataupun masih aktif berisiko terjadinya air asam tambang (acid mine drainage) yang banyak mengandung logam berat, seperti $\mathrm{Pb} \mathrm{Cd}$, $\mathrm{Zn}$, Al (Naidoo 2017). Logam berat yang terkandung dalam air asam tambang antara lain $\mathrm{Cd}, \mathrm{Cu}, \mathrm{Zn}$ (Achterberg et al. 2003). Hakiki (2018) menyebutkan bahwa tanah bekas tambang batubara dan sekitarnya terkontaminasi $\mathrm{Pb}, \mathrm{Fe}$ dan $\mathrm{Zn}$ yang telah melebihi ambang batas. Bhuiyan et al. (2010) menyatakan bahwa telah terjadi kontaminasi $\mathrm{Mn}, \mathrm{Zn}, \mathrm{Pb}$ dan $\mathrm{Ti}$ akibat aktivitas tambang batubara.

Aktivitas pertanian ataupun perkebunan sering menggunakan pestisida dan fungisida untuk pengendalian hama. Kedua bahan tersebut mengandung senyawa-senyawa beracun yang dapat mencemari lingkungan. USEPA (1989) menyebutkan bahwa senyawa kadmium (Cd) merupakan salah satu bahan yang bersifat racun yang terdapat dalam pestisida. Kandungan bahan aktif fungisida merupakan belerang, kapur dan tembaga sulfat (senyawa $\mathrm{Cu}$ ) yang masih digunakan sampai awal abad duapuluh (Russell 2005).

Pada kajian ini dijumpai bahwa kontaminasi logam berat sangat terkait dengan aktivitas tambang batubara, bekas pengeboran minyak bumi, dan atau perkebunan kelapa sawit. Logam yang dimaksud adalah $\mathrm{Cu}, \mathrm{Cd}$ dan $\mathrm{Pb}$. Lokasi yang ditemukan tercemar oleh logam tersebut adalah pada air sungai, air laut dan sedimen laut. Lokasi sungai yang tercemar hampir semuanya berdekatan dengan lokasi tambang. Pencemaran yang terjadi di laut baik pada air maupun sedimen berasal dari sungai pada bagian hulu yang tercemar.

Hasil kajian menunjukkan hampir semua sampel yang ada di sungai tercemar logam berat. Hal ini sesuai dengan temuan dari Forstner dan Wittman (1981) yang mengungkapkan bahwa konsentrasi logam berat di air sungai dapat meningkat beberapa ribu kali akibat limbah pertambangan dan tingginya konsentrasi logam berat berhubungan dengan sumber pencemar yang ada disekitarnya.

Hanya saja pada kajian ini pola pencemaran untuk logam $\mathrm{Cd}$ dan $\mathrm{Cu}$ berbeda dengan yang disampaikan oleh Endan dkk. (2011). Dalam kajiannya di Teluk Banten, pola distribusi logam berat pada air laut, rumput laut dan sedimen menunjukkan konsentrasi logam berat cenderung bersifat lokal dan berhubungan dengan sumber pencemarnya, sedangkan dalam 10 kajian ini logam berat terbawa oleh aliran sungai dari hulu hingga menyebar ke laut. Terlihat bahwa pola distribusi logam berat tidak bersifat lokal. Hal tersebut dimungkinkan terjadi karena gaya gravitasi aliran sungai dari hulu ke muara sungai hingga masuk ke perairan laut, kemudian karena adanya pasang surut dan aktivitas arus menyebabkan logam berat menyebar jauh dari sumber pencemarnya.

Dengan hasil yang diperoleh maka pencemaran logam berat dapat menyebar jauh dari sumbernya, terutama jika terjadi pada aliran sungai yang terbawa hingga menuju laut. Kondisi laut yang dinamis adanya pasang surut dan arus mampu membawa logam berat lebih jauh dari sumbernya. Logam Cd yang melebihi ambang batas pada sampel air sungai hanya ditemukan pada stasiun $\mathrm{Sg} 7$ (dekat muara), namun $\mathrm{Cd}$ terdeteksi melebihi ambang batas tersebar pada semua sampel air laut dan sedimen laut. Pada lokasi di laut berdasarkan gambar citra satelit tidak ditemukan aktivitas manusia sebagai sumber pencemar, sehingga dimungkinkan sumber pencemar berasal dari stasiun $\mathrm{Sg} 7$, logam Cd telah bergerak jauh dari sumber pencemarnya.

Logam $\mathrm{Zn}$ yang hanya ditemukan pada air sumur. Karena air sumur bersifat statis, logam $\mathrm{Zn}$ tidak masuk hingga ke laut. Logam $\mathrm{Zn}$ terdeteksi melebihi ambang batas pada area pemukiman dan atau perkebunan. Menurut Hutagalung (1984), Zn merupakan unsur logam berat digunakan pada campuran logam, galvanisir, cat, baterai dan karet. Sumber Zn di perairan diduga berasal dari kapal, kegiatan perdagangan dan fasilitas pariwisata (Supriyantini dkk. 2016), limbah industri dan rumah tangga (Yudo 2006) dan buangan sampah (Nasution 2012). Kajian Nasution (2012) menyebutkan bahwa semakin dekat jarak sumur dengan tempat pembuangan sampah maka kandungan $\mathrm{Zn}$ semakin tinggi.

Sementara itu, pola sebaran logam $\mathrm{Pb}$ lebih bersifat lokal, terakumulasi pada lokasi yang dekat dengan sumber pencemar. Konsentrasi logam $\mathrm{Pb}$ yang melebihi ambang batas hanya ditemukan pada dua stasiun di sungai, yaitu $\mathrm{Sg} 9$ dan $\mathrm{Sg} 1$. Lokasi tersebut berdekatan dengan sumur pengeboran minyak peninggalan Belanda yang sudah tidak berproduksi. Logam $\mathrm{Pb}$ tidak ditemukan pada sampel air dan sedimen laut. Hal ini dijelaskan oleh Carls dkk. (1995) kontaminasi dari kegiatan pemboran dan produksi migas dapat tersebar luas dan persisten, tetapi secara umum terlokalisasi di sekitar lokasi kegiatan. Penelitian pada 18 sampel tanah di lokasi pengeboran migas di pesisir Nasional pulau Padre menunjukkan bahwa empat logam berat mempunyai konsentrasi yang tinggi, yaitu $\mathrm{Ba}, \mathrm{Cr}, \mathrm{Pb}$ dan $\mathrm{Zn}$. Pichtel 
(2016) menambahkan bahwa lapangan migas biasanya memproduksi air yang mengandung logam berat seperti merkuri dan $\mathrm{Pb}$ dengan konsentrasinya tergantung pada formasi geologinya.

Keberadaan $\mathrm{Pb}$ di perairan akan berpengaruh terhadap kehidupan di dalamnya. Distribusi $\mathrm{Pb}$ pada ekosistem ditengarai tidak mempunyai sifat biomagnifikasi kearah trophic level yang lebih tinggi. Konsentrasi $\mathrm{Pb}$ yang tertinggi berada dalam sedimen dan akan menurun secara berurutan seperti berikut: sedimen $>$ plankton $>$ benthos $>$ ikan (Nagpal 1987 dalam Idaho Cobalt Project 2008).

Konsentrasi $\mathrm{Cu}$ terdeteksi melebihi ambang batas pada tujuh stasiun di sungai dan pada air laut berada di mulut sungai serta dijumpai ke arah laut lepas (stasiun L3) pada sampel sedimen dan tidak melebihi ambang batas pada sampel airnya. Kontaminasi $\mathrm{Cd}$ dijumpai pada sampel air laut dan sedimen melebihi ambang batas (SEPA 2002) pada semua stasiun di laut. Kondisi ini dapat terjadi karena adanya pembilasan akibat pengaruh dari aktivitas arus dan gelombang. Hal ini sesuai dengan pendapat Susantoro dkk. (2015) bahwa secara umum konsentrasi logam berat cenderung lebih tinggi di muara sungai dibandingkan ke arah laut lepas.

Pada lokasi kajian, tingginya konsentrasi $\mathrm{Cu}$ diduga karena adanya pertambangan batubara secara terbuka. Hal ini sesuai dengan pendapat Cole dkk. (1999) bahwa adanya pertambangan, peleburan, pemurnian dan pembakaran batubara menjadi sumber tinginya konsentrasi $\mathrm{Cu}$. Yudo (2006) menambahkan bahwa konsentrasi $\mathrm{Cu}$ yang tinggi dapat disebabkan oleh erosi dari batuan mineral dan akibat aktivitas manusia. Nasution \& Siska (2011) menegaskan bahwa sumber logam berat $\mathrm{Cu}$ di perairan adalah deposit-deposit yang terbawa sungai, penambangan dan pengerukan.

Tembaga $(\mathrm{Cu})$ adalah logam yang terjadi secara alami di lingkungan, dan juga pada tumbuhan dan hewan. Tingkat tembaga yang rendah sangat penting untuk pemeliharaan kesehatan yang baik. Tingkat tinggi dapat menyebabkan efek berbahaya seperti iritasi hidung, mulut dan mata, muntah, diare, kram perut, mual, dan bahkan kematian (ATSDR 2004).

Pada delta sungai yang merupakan area pertambakan cenderung mempunyai konsentrasi $\mathrm{Cu}$ yang yang melebihi ambang batas yang ditentukan (Gambar 3). Bila merujuk pada Peraturan Pemerintah RI Nomor 82 tahun 2001 dan Kepmen-LH 51 tahun 2004 Lampiran III untuk biota laut, kondisi ini kurang layak untuk kegiatan budidaya perikanan.

Seperti $\mathrm{Cu}$, konsentrasi $\mathrm{Cd}$ dapat disebabkan dari aktivitas pertambangan batubara (Forstner \& Wittman 1981; Salminen et al. 2006). Dijelaskan oleh Wang et al. (2014) bahwa konsentrasi $\mathrm{Cd}$ di perairan dan sedimen dapat berasal dari aktivitas antropogenik. Rachmaningrum dkk. (2015) menambahkan bahwa selain aktivitas antropogenik secara alami, lapisan bumi juga berperan sebagai sumber $\mathrm{Cd}$. Cd selalu bercampur dengan logam lain, terutama dalam pertambangan. Konsentrasi Cd jumlahnya relatif kecil, namun dapat meningkat karena proses pembuangan limbah industri. $\mathrm{Cd}$ berpengaruh terhadap manusia dalam jangka waktu panjang dan dapat terakumulasi tubuh khususnya hati dan ginjal (Palar 2004). Pada ikan akumulasi logam berat terutama Cd lebih banyak di insang dan hati dibandingkan pada otot (ElMoselhy et al. 2014).

Dibandingkan dengan hasil penelitian lainnya seperti yang disajikan oleh Tabel 10, konsentrasi $\mathrm{Cu}$ dan $\mathrm{Cd}$ di Pelabuhan Pasuruan dan Selat Rupat, jauh lebih rendah dibandingkan hasil dalam penelitian ini. Demikian halnya dengan hasil penelitian di Delta Berau, kontaminasi $\mathrm{Cu}$ dan $\mathrm{Cd}$ masih lebih tinggi dalam penelitian ini. Rerata kontaminasi $\mathrm{Cu}$ pada sedimen dalam penelitian ini adalah $18,458 \mathrm{mg} / \mathrm{kg}$ dan $\mathrm{Cd} \mathrm{1,24}$ $\mathrm{mg} / \mathrm{kg}$. 


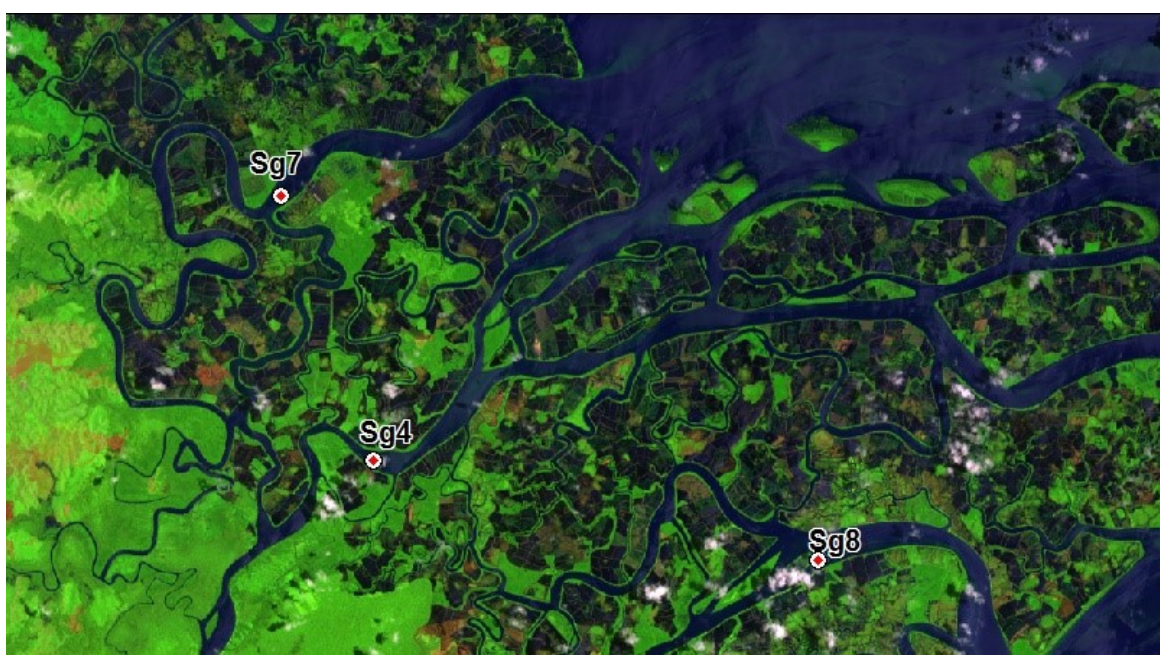

Gambar 3. Sebagian besar wilayah estuari merupakan area pertambakan.

Figure 3. A large number of delta area consists of brackishwater pond.

Tabel 10 . Konsentrasi logam berat ( $\mathrm{mg} / \mathrm{kg}$ bobot kering) dalam sedimen di beberapa perairan laut di Indonesia.

Table 10. The concentration of heavy metals ( $\mathrm{mg} / \mathrm{kg}$ dry weight) in sediments in several other marine waters in Indonesia

\begin{tabular}{|c|c|c|c|c|c|}
\hline \multirow{3}{*}{ Locations } & \multicolumn{4}{|c|}{ Heavy metals concentration (mg/kg dry weight) } & \multirow{3}{*}{ References } \\
\hline & \multicolumn{2}{|r|}{$\mathrm{Cu}$} & \multicolumn{2}{|r|}{$\mathrm{Cd}$} & \\
\hline & Average & Range & Average & Range & \\
\hline Pasuruan Harbour & 0,2514 & $0,0901-0,3942$ & 0,0611 & $0,0343-0,1002$ & Aminah et al. (2010) \\
\hline $\begin{array}{l}\text { Rupat Strait, } \\
\text { Dumai }\end{array}$ & - & - & 0,04 & $0,02-0,1$ & $\begin{array}{l}\text { Syahminan et al. } \\
\text { (2015) }\end{array}$ \\
\hline Delta Berau & 16,537 & $1,575-34,112$ & 0,059 & $0,022-0,125$ & Afriansyah (2009) \\
\hline
\end{tabular}

\section{Kesimpulan dan Saran}

\section{Kesimpulan}

Secara umum logam berat yang terdeteksi melebihi ambang batas di Tanjung Selor dan sekitarnya, Kabupaten Bulungan, Provinsi Kalimantan Utara adalah $\mathrm{Cu}, \mathrm{Pb}, \mathrm{Cd}$ dan $\mathrm{Zn}$. $\mathrm{Cu}$ ditemukan melebihi ambang batas pada sampel air sungai, air laut dan sedimen. $\mathrm{Pb}$ hanya ditemukan pada air sungai dan Zn hanya pada air sumur. Sementara itu Cd ditemukan pada satu stasiun sungai $\mathrm{Sg} 7$, dan ditemukan menyebar pada sampel air laut dan sedimen. Logam berat lainnya, Hg, $\mathrm{Cr}$, dan As ditemukan masih dalam ambang batas yang diijinkan.

Berdasarkan kajian ini, diduga sebagian besar sumber pencemar adalah berasal dari aktivitas pertambangan batubara, bekas pengeboran minyak dan atau perkebunan kelapa sawit.Konsentrasi $\mathrm{Zn}$ yang tinggi di area pemukiman dan pekebunan kelapa sawit kemungkinan berasal dari limbah rumah tangga, seperti dekat dengan pembuangan sampah.Hasil kajian ini menunjukan bahwa wilayah delta dapat menjadi perangkap akumulasi logam berat, ditunjukkan tingginya konsentrasi logam berat pada wilayah delta tersebut.

\section{Saran}

Perlu pengawasan yang lebih teliti terhadap aktivitas pertambangan batubara dan perkebunan kelapa sawit serta aktivitas lainnya yang disinyalir dapat meningkatkan konsentrasi logam berat pada lingkungan sekitar. Konsentrasi logam berat cenderung terperangkap di wilayah delta, aktivitas budidaya perikanan seperti tambak berlangsung. Hal ini perlu dilakukan kajian lanjutan mengenai konsentrasi logam berat pada hasil budidaya tambak pada lingkungan yang tercemar logam berat. 


\section{Persantunan}

Terima kasih kami ucapkan kepada Laboratorium Produktivitas Lingkungan, Institut Pertanian Bogor yang telah membantu menganalisis sampel air dan sedimen. Terima kasih juga kami ucapkan kepada semua pihak yang telah membantu dalam kajian ini.

\section{Daftar Pustaka}

Achterberg, E.P, V.M.C. Herzl, C.B. Braungardt, and G.E. Millward. 2003. Metal behaviour in an estuary polluted by acid mine drainage: the role of particulate matter. Environmental Pollution 121: 383-292.

Afriansyah, A. 2009. Konsentrasi Kadmium (Cd) dan Tembaga $(\mathrm{Cu})$ dalam Air, Seston, Kerang dan Fraksinasinya dalam Sedimen di Perairan Delta Berau, Kalimantan Timur. [Skripsi]. Program Studi Ilmu dan Teknologi Kelautan. Fakultas Perikanan dan Ilmu Kelautan. Institut Pertanian Bogor.

Aminah, S., D. Yona, dan R. Dyah. 2016. Sebaran Konsentrasi Logam Berat $\mathrm{Cu}$ (Tembaga) dan Cd (Kadmium) Pada Air dan Sedimen di Perairan Pelabuhan Pasuruan, Jawa Timur. Seminar Nasional Perikanan dan Kelautan VI, Fakultas Perikanan dan Ilmu Kelautan, Universitas Brawijaya Malang.

Arimby, C., W. Lestari dan Y. Azis. 2014. Pemanfaatan Azzola pinata R.Br dalam Penyerapan Zn dari Limbah Cair Pabrik Karet sebagai Fitoremediator. Jurnal Online Mahasiswa Fakultas Perikanan dan Ilmu Kelautan, Universitas Riau, 1(2): 1-8.

Atlas, E. and C.S. Giam. 1981. Global Transport of Organic Pollutants: Ambient Concentrations in the Remote Marine Atmosphere. Journal Science 211(4478): 163-165

DOI: $10.1126 /$ science.211.4478.163.

ATSDR (Agency for Toxic Substances and Disease Registry). 2004. Toxicological Profile for Copper. Atlanta, GA: U.S. Department of Health and Human Services, Public Health Service.

BPMigas (Badan Pelaksana Kegiatan Usaha Hulu Minyak dan Gas Bumi). 2011. Pedoman Tata Kerja Tentang Environmental Baseline Assessment. Nomor PTK-045/BP00000/2011 (revisi-0).

Bhuiyana, M.A.H., L. Parvezb, M.A. Islam, S.B. Dampared, and S. Suzukia. 2010. Heavy Metal Pollution of Coal Mine-Affected
Agricultural Soils in the Northern Part of Bangladesh. Journal of Hazardous Materials 173: 384-392.

Carls, E.G., D. B. Fenn and S.A. Chaffey, 1995. Soil Contamination by Oil and Gas Drilling and Production Operations in Padre Island National Seashore, Texas, U.S.A. Journal of Environmental Management 45(3): 273-286.

CCME (Canadian Council of Ministers of the Environment). 2001. Canadian Sediment Quality Guidelines for the Protection of Aquatic Life.

Cole, S., I.D. Codling, W. Par and T. Zabel, 1999. Guidelines for Managing Water Quality Impacts within UK European Marine Sites. UK Marine SAC Project. 448 pages.

Dean, J.G., F.L. Bosqui and K.H. Lanouette. 1972. Removing Heavy Metals form Waste Water. Environmental Science \& Technology 6 : 518-522. DOI: 10.1021/es60065a006.

Effendi, H., 2012. Telaah Kualitas Air. Bagi Pengelolaan Sumber Daya dan Lingkungan Perairan. Cetakan ke 7. Penerbit Kanisius (Anggota IKAPI). Yogyakarta.

El-Moselhy, Kh. M., A.I. Othman, H. A. El-Azem and M.E.A. El-Metwally, 2014. Bioaccumulation of Heavy Metal in Some Tissues Fish in the Red Sea, Egypt. Jurnal of Basic and Applied Sciences 1(2) : 95-105.

Endan, S., K. Kawamura and E. Soeyanto, 2011. Assessment of the Heavy Metals and Nutrients Status in the Seawater, Sediment and Seagrass in Banten Bay, Indonesia and Their Distributional Patterns. Journal of Fisheries International 6 (1): 18-25.

Forstner, U. and G.T.W. Wittmann, (eds), 1981. Metal pollution in the Aquatic Environment. Springer, Berlin Heidelberg New York.. DOI 10.1007/978-3-642-69385-4. 486 pages.

Hakiki, I.A. 2018. Analisa Logam Berat (Pb, Fe, Zn) pada Tanah Bekas Lahan Tambang Batubara dan Manfaatnya Sebagai Handout Kimia Lingkungan Pada Materi Pencemaran Tanah. Skripsi. Fakultas Keguruan dan Ilmu Pendidikan. Universitas Jambi.

Hutagalung, H.P., 1984. Logam Berat dalam Lingkungan Laut. Oseana IX(1): 11-20.

Idaho Cobalt Project, 2008. Final Environmental Impact Statement. Volume II. The U.S. Department of Agriculture (USDA). Washington D.C.

Keputusan Menteri Lingkungan Hidup No. 51 Tahun 2004 Tentang Baku Mutu Air Laut.

Mason, C.F. 1993a. Biology of freshwater Pollution. Second Edition. Longman Scientific and Technical, New York. 351 pages. 
Mason, C. F. 1993b. Aquatic Pollution (2nd Ed.), E. A. Laws, John Wiley and Sons. 611 pages.

Moore, J. W. and S. Ramamoorthy. 1984. Heavy Metals in Natural Waters. Applied Monitoring and Impact Assessment. Springer Verlag. New York Inc. 270 pages.

Naidoo, S. 2017. Acid Mine Drainage in South Africa Development Actors, Policy Impacts, and Broader Implications. SpringerBriefs in Environmental Science.

Nasution, S. dan M. Siska, 2011. Kandungan Logam Berat Kadmium (Cd) dan Tembaga (Cu) pada Sedimen dan Siput Strombus canarium Pantai Pulau Bintan. Jurnal Natur Indonesia 13(3): 262 - 268.

Nasution, H.I. 2012. Analisis Kandungan Logam Berat Besi (Fe) dan Seng ( $\mathrm{Zn})$ pada Air Sumur Gali di sekitar Tempat Pembuangan Akhir Sampah. Jurnal Penelitian Saintika (Sain, Teknologi dan Rekayasa 12(2): 165169.

O'Neill, K. and H. Kerr. 2004. Standard Operating Procedure. Wastewater Sampling Procedures. Donegal County Council Laboratory. Revision 0.2 pages.

Palar, H., 2004. Pencemaran dan Toksikologi Logam Berat. Penerbit Rineka Cipta. Jakarta

Peraturan Pemerintah RI Nomor 82 Tahun 2001 Tentang Pengelolaan Kualitas Air dan Pengendalian Pencemaran Air.

Pichtel, J. 2016. Oil and Gas Production Wastewater: Soil Contamination and Pollution Prevention. Applied and Environmental Soil Science8: pp: 1-24.

Peraturan Menteri Kesehatan RI. No.416/MENKES/PER/IX/1990 Tentang Syarat-Syarat dan Pengawasan Kualitas Air.

Rachmaningrum, M., E. Wardhani dan K. Pharwati., 2015. Konsentrasi Logam Berat Kadmium (Cd) pada Perairan Sungai Citarum Hulu Segmen DayeuhkolotNanjung. Jurnal Reka Lingkungan 3(1): 1 11.

Russell, PE. 2005. A century of fungicide evolution. Journal of Agricultural Science $143 ; 11-25$

Salminen, R., M.J. Batista, M. Bidovec, A. Demetriades and B. De Vivo, 2006. Geochemical Atlas of Europe, part I, Background Information, Methodology and Map. Geological Survey of Finland, Espoo, Finland.

Sanusi, H.S., 2006. Kimia Laut, Proses Fisik Kimia dan Interaksinya dengan Lingkungan. Departemen Ilmu dan Teknologi Kelautan,
Fakultas Perikanan dan Ilmu Kelautan, Institut Pertanian Bogor. 188 hal.

Singovszka, E., A. Petrilakova, M. Balintova and M. Holub. 2014. The Impact of Mining Activities on the Sedimen Quality in Water Reservoir Ruzin I. (Slovakia). "The 9th International Conference "Environmental Engineering”. 22-23 May 2014. Vilnius, Lithuania.

Siregar, S.A., 2005. Instalasi Pengolahan Air Limbah. Penerbit Kanisius. Yogyakarta.

Suhelmi, Y. I. R. and M. Ramdhan, 2014. Identifikasi Pulau di Muara Sungai Berdasarkan Kaidah Toponimi (Studi kasus: Muara Sungai Bulungan, Kab. Bulungan, Provinsi Kalimantan Utara. Forum Geografi 28(1): $43-56$.

Supriyantini, E., S. Sedjati dan Z. Nurfadli. 2016. Akumulasi Logam Berat Zn (seng) pada Lamun Enhalus acoroides dan Thalassia hemprichii di Perairan Pantai Kartini jepara. Buletin Oseanografi Marina 5(1): 14-19.

Susantoro, T.M., D. Sunarjanto dan A. Andayani, 2015. Distribusi Logam Berat pada Sedimen di Perairan Muara dan Laut Propinsi Jambi. Jurnal Kelautan Nasional 10(1) : 1-11.

Syahminan, E. Riani, S. Anwar, dan Rifardi. 2015. Telaahan Logam Berat Pb Dan Cd Pada Sedimen di Perairan Barat Laut DumaiRiau. Jurnal Pengelolaan Sumberdaya Alam dan Lingkungan 5 (2): 133-140

SEPA (Swedish Environmental Protection Agency). 2000. Environmental Quality Criteria. Coasts and Seas. Swedish Environmental Protection Agency. Report 5052, $\quad$ pp. $\quad 51 \quad$ - $\quad 75$. https://www.naturvardsverket.se/Documents/ publikationer/620-6034-1.pdf

Undang-Undang Republik Indonesia Nomor 20 Tahun 2012 Tentang Pembentukan Provinsi Kalimantan Utara.

USEPA (United States Environmental Protection Agency). 1989. Inert Ingredients of Pesticide Products.

https://www.epa.gov/sites/production/files/20 15-10/documents/fr54.pdf

Wang, J., R. Liu, P. Zhang, W. Yu, Z. Shen and C. Feng. 2014. Spatial Variation, Environmental Assessment and Source Identification of Heavy Metals in Sedimens of the Yangtze River Estuary. Marine Pollution Bulletin 87(1-2): 364 -373.

Yudo, S. 2006. Kondisi Pencemaran Logam Berat di Perairan Sungai DKI Jakarta. Jurnal Air Indonesia $\quad 2(1)$ : $1-15$. 